\title{
Kinesio taping: application and results on pain: systematic review
}

\author{
Kinesio taping: aplicação e seus resultados sobre a dor: revisão sistemática \\ Kinesio taping: Aplicación y sus resultados sobre el dolor: una revisión sistemática \\ Dérrick Patrick Artioli', Gladson Ricardo Flor Bertolini²
}

\begin{abstract}
I Kinesio taping is being increasingly used under several conditions; however, its hypoalgesic effect and mechanism of action do not show scientific results. Therefore, the aims of this study were to describe the principles of the method and mainly to analyze the results of clinical trials with control groups, related to pain with Kinesio taping. The PubMed, SciELO, Lilacs, Scirus and Academic Google databases were consulted, using the keywords: Kinesio Taping and Kinesio Tape, either associated or not to pain. Ten clinical trials related to pain and Kinesio taping were selected, assessed by using the PEDro scale, and its results were analyzed. Kinesio taping provided higher, similar or lower pain reduction than in other groups (control, placebo or technique). The application continues to use the principles of Kenzo Kase, the gate control theory being the most described so far to justify the hypoalgesic effect; and the effects were only found in short-term (24 hours to 1 week). Pain relief provided by Kinesio taping was similar or slightly superior to other interventions, not representing a reason for it to be the main treatment of choice. However, it can be considered an adjunct or complementary technique.
\end{abstract}

Keywords I Physical Therapy Specialty; Physical Therapy Modalities; Rehabilitation.

RESUMO I O Kinesio taping vem sendo utilizado cada vez mais em diversas condições, porém, seu efeito hipoalgésico e mecanismo de ação não apresentam resultado científico. Portanto, os objetivos deste estudo foram descrever os princípios do método e, principalmente, analisar quais foram os resultados dos ensaios clínicos, com grupo controle, referente à dor com Kinesio taping. Foram pesquisadas as bases de dados PubMed, SciELO, Lilacs, Scirus e Google Acadêmico, com o uso das palavras-chave: Kinesio Taping e Kinesio Tape associadas ou não à dor. Foram selecionados 10 ensaios clínicos referentes à dor e Kinesio taping, os mesmos foram avaliados por meio da escala PEDro e seus resultados analisados. Kinesio taping proporcionou redução da dor superior, semelhante ou inferior a outros grupos (controle, placebo ou técnica). A aplicação continua utilizando os princípios de Kenzo Kase, a teoria das comportas é a mais descrita até o momento para justificar o efeito hipoalgésico e os efeitos só foram encontrados em curto prazo (24 horas a 1 semana). A redução da dor proporcionada por Kinesio taping foi semelhante ou pouco superior a outras intervenções, não representando motivo para que esse seja o principal tratamento de escolha, sendo considerada técnica adjunta ou complementar.

Descritores I Fisioterapia; Modalidades de Fisioterapia; Reabilitação.

RESUMEN I El Kinesio taping viene siendo utilizado cada vez más en diversas condiciones, sin embargo, su efecto hipoalgésico y mecanismo de acción no presentan resultado científico. Por lo tanto, los objetivos de este estudio fueron describir los principios del método y principalmente analizar cuáles fueron los resultados de los ensayos clínicos, con grupo control, en cuanto

Study conducted at the Núcleo de Fisioterapia Ortopédica, Desportiva e Terapias Alternativas (NAFDT) of Centro Universitário Lusíada (UNILUS) - Santos (SP) and Laboratory of Study of Injuries and Physical Therapy Resources of the Universidade Estadual do Oeste do Paraná (UNIOESTE) - Cascavel (PR), Brazil.

'Graduate Program of Musculoskeletal Physical Therapy by the Santa Casa de Misericórdia de São Paulo; Centro Universitário Lusíada (UNILUS) - Santos (SP), Brazil.

${ }^{2}$ Graduate Program of Health Sciences Applied to the Locomotor System by the School of Medicine of Ribeirão Preto of the Universidade de São Paulo (USP); Universidade Estadual do Oeste do Paraná (UNIOESTE) - Cascavel (PR), Brazil. 
al dolor con Kinesio taping. Fueron investigadas las bases de datos PubMed, SciELO, Lilacs, Scirus y Google Académico, utilizando las palabras clave: Kinesio taping y Kinesio Tape asociada o no al dolor. Fueron seleccionados 10 ensayos clínicos relacionados con el dolor y Kinesio taping. Los mismos fueron evaluados mediante la escala Pedro y sus resultados analizados. Kinesio taping proporcionó reducción del dolor superior, similar o inferior a otros grupos (control, placebo o técnica). La aplicación sigue utilizando los principios de Kenzo Kase, la teoría de las compuertas es la más descrita hasta la fecha para justificar el efecto hipoalgésico y los efectos sólo fueron encontrados en corto plazo (de 24 horas a 1 semana). La reducción del dolor proporcionada por Kinesio taping fue similar o poco más alta que otras intervenciones, lo que no representa razón para que ese sea el tratamiento principal de elección, y es considerado como una técnica adjunta o complementaria.

Palabras clave I Fisioterapia; Modalidades de Fisioterapia; Rehabilitación.

\section{INTRODUCTION}

Originally developed in 1973 by Kenzo Kase in Japan, the Kinesio taping (KT), also known as elastic bandage, is a relatively new method that has become popular over the last 10 years, after the disclosure provided in major events such as the Olympic Games $^{1-4}$. The tape is free of latex, with acrylic adhesive capacity, and activated by body heat, made of elastic polymer strand wrapped in cotton fibers (100\%). Its features exceed the tapes commonly used in bandages, for it allows quick drying, longer time of usage and thinner and more elastic material (stretching / longitudinal stretching of 55-60\% in resting position or overall elasticity of 120-140\%), which facilitates involving tissues and joints accurately. According to its creator, KT provides: (1) Correction of muscle function by strengthening weak muscles; (2) cutaneous stimulation which facilitates or limitates movement; (3) aid in the reduction of edema by directing exudates towards the lymphatic duct and the lymph nodes; (4) correction of joint positioning for easing muscle spasms; and (5) reduction of pain by neural pathways ${ }^{1,3,5-10}$.

With so many possible benefits, in addition to its use in classical orthopedic conditions ${ }^{10}$, applications in various disorders - such as, cerebrovascular accident $^{11,12}$, drooling in cerebral palsy ${ }^{4}$, multiple sclerosis $^{13}$, post-mastectomy ${ }^{14,15}$, among others - arise. Although widely used in practice, the mechanism of action of KT is still not completely understood, and the scientific evidence are limited and controversial in relation to the hypoalgesic effect ${ }^{3,5-7,10,16}$. Therefore, it is necessary to analyze whether the use of KT, in pain, generates higher, lower or similar effects to other forms of treatment effects, if it is just a placebo, or if incapable of providing significant change to a control group. The objective of this study was to conduct a systematic review in order to report the principles of the method and, specially to analyze what were the results of clinical trials with a control group regarding pain with the KT.

\section{METHODOLOGY}

For this study, the PubMed, SciELO, Lilacs, Scirus, Google Scholar databases were consulted, as well as a manual search in indexed scientific journals was developed, with the following keywords: "Kinesio Taping"; "Kinesio Tape"; and "Kinesiotaping"; associated or not with "pain". In order to be included, the studies should provide access to the full assessment (availability of the material in an open way or magazines registered in the CAPES Journal), in the form of clinical trial with a control group that evaluated pain with the application of KT, without age limitation or language of the manuscript. The researches which did not use pain as a comparison parameter as to the use of $\mathrm{KT}$ - which used non-elastic bandages as a way of treatment - or the researches that did not involve comparative groups, were excluded. The studies which fulfilled the inclusion criteria were assessed by the Physiotherapy Evidence Database (PEDro ${ }^{17}$ scale, used by two experienced professionals in musculoskeletical physical therapy, without aiming to exclude data as to the scores obtained, i.e., just point out the quality of the methodology of each study. In the sequence, the Statistica 7 software was used in order to analyze the data. Figure 1 presents the quantitative data of the conducted search. 


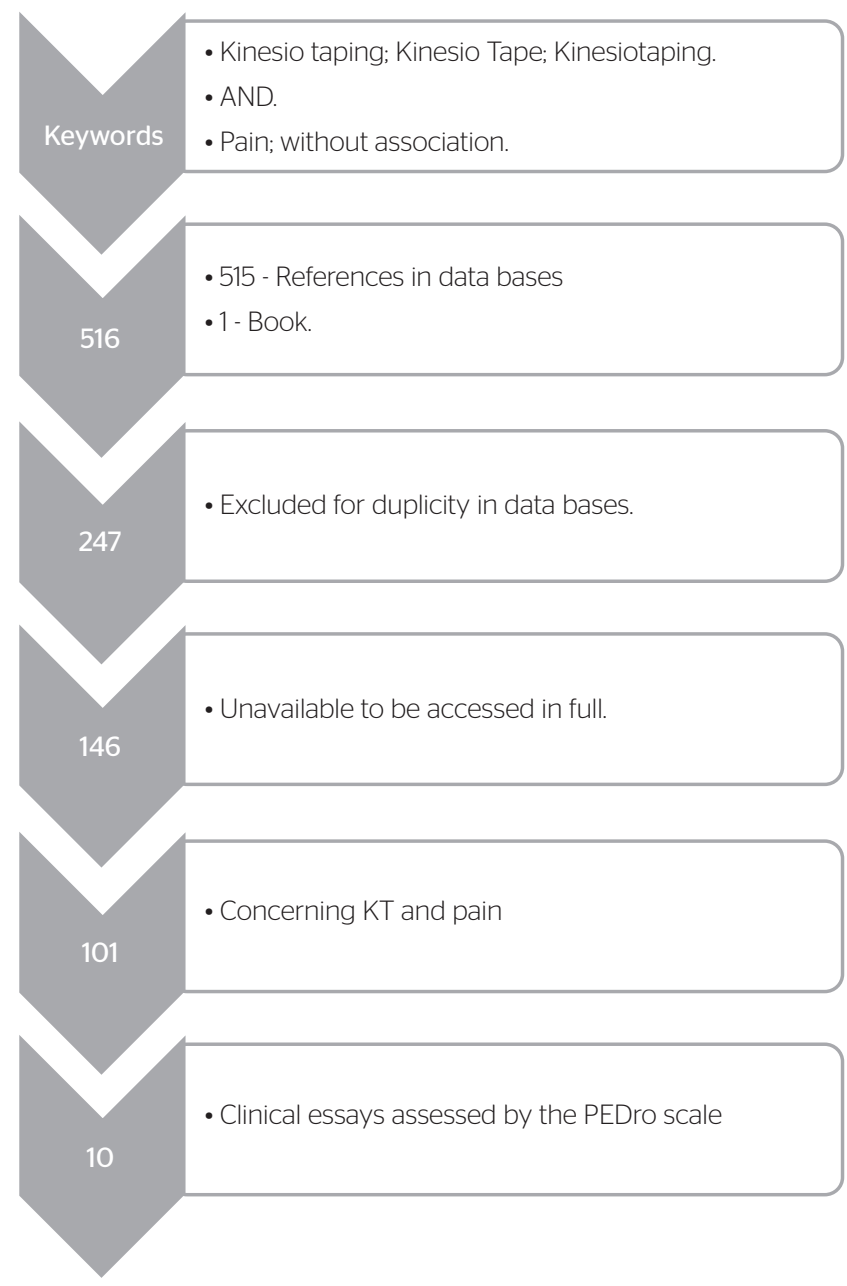

Figure 1. Flowchart of the data found in the search on different databases

\section{RESULTS AND DISCUSSION}

Before discussing the individual analysis of each study, it is noteworthy to pinpoint the similarities among them when it comes to the basic requirements of KT, concerning the ways for application, the skin preparation, the positioning, the tension, the direction and the time of use. Among the forms of application of KT, the tape may be cut in "Y", "I", "X", "fan", "web" (modified "fan") and "donut" shapes, which will depend on the size of the affected muscle and on the desired treatment. These forms of application are used, respectively, for muscle weakness (facilitatory or inhibitory effect), pain and swelling, biomechanical correction, lymphatic drainage (both "fan" and "web"), focused edema or specific area (sports) ${ }^{1}$.

The skin must be free of lotions or moisturizing oils prior to application. When removing the protective sheet of the adhesive, minimum contact should be done so that the adhesive capacity is preserved, therefore, the adhesive protection shouldn't be completely removed. In basic corrective techniques, the positioning of the kinesio tape must reproduce the positioning of the therapist's hands on the patient. The base of the tape must be positioned $5 \mathrm{~cm}$ below the origin or above the insertion, without inputting any tension, to prevent discomfort. After stretching the muscle, the tensioned elastic tape must be positioned on top of it. If the KT is too stretched out, there will be reducing of the effect, therefore, it is best to have less rather than excessive ten$\operatorname{sion}^{2,3}$. Graded by percentage, the traction of the elastic band is described as one of the key factors for successful implementation, that is: full tension $100 \%$, intense $75 \%$, moderate $50 \%$, just the removal of the protective sheet or light $15-25 \%$, very light $0-15 \%$, no tension $0 \%{ }^{1}$.

The direction towards which the tape is to be applied will depend on the purpose of the treatment. As a basic rule, it is placed from the insertion towards the muscle origin (15-25\%) in order to inhibit the muscle function in acute situations, caused by overuse or muscle overstretching. In the case of chronically weakened muscles, or when the increase of muscle contraction/activation is desired, KT should be positioned from the origin to the insertion $(25-50 \%)^{2,3,5-7,9,10,16,18}$.

In about 10 minutes the patient will not notice its presence on the skin, and in about 20 minutes it will be fully adhered to the skin. The application shall last for 3-5 days, when the decreasing of the elastic polymer function occurs ${ }^{1,5,16}$.

Application forms may vary, but in the verified studies, they were all based on the principles of Kenzo Kase's book $^{1-3,5-7,9,10,16,18}$.

After the search for references, 10 studies met the inclusion criteria, the minimum methodological quality was 5 , the maximum was 9 and the average was $7.9 \pm 1.6$ points, determined by the PEDro scale. In general, 415 subjects participated in studies comparing KT with another group (control, placebo or intervention), 4 presented superior results, 5 similar ones and 1 inferior to counterintervention (Table 1).

The authors of the studies in which the KT group had greater reduction in pain, when compared to intervention, described that clinically, it may not be relevant, because the algic decrease was minimally better, and that afterwards the results would be equivalent to the counterintervention ones. Moreover, the described improvement would only be a short-term one (24 hours to 1 week $)^{2,3,5,7,10}$. Only 1 of the studies showing superior results with the use of KT obtained a relatively low score (5), the other 3 of them evidenced high methodological quality (9) by the PEDro scale, resulting in an average of $8 \pm 2$ points. 
In the studies in which the benefits observed were similar to the other group's, it does not mean that there was no decrease in the patient's pain with the use of KT, but that its application would be as efficient as the use of another technique, which does not justify using it as the main treatment to be chosen. As an example, one can use the study of Saavedra-Hernández et al. ${ }^{18}$ which, from among the other selected ones, was the one involving the largest number of participants, with high methodology quality, according to the PEDro scale and that, when comparing KT to cervical manipulation, found equivalent decrease of pain after one week. However, as illustrated by the authors, the limitation was the absence of a group with no intervention (control) and placebo groups, which would bring more conclusive information. In another study, which compared KT and placebo groups for shoulder pain, it was only during the first three days that the results of the first group were significantly higher, but later on, the results revealed themselves equivalent between groups ${ }^{7}$. Unlike the last two studies, a six-week rehabilitation program for patellofemoral syndrome were compared, one group with and one without the addition of KT. In both of them there was an algic reduction, with no intergroup difference ${ }^{6}$. Therefore, KT cannot be considered superior nor inferior to the other interventions used in five of the studies, which nearly obtained top marks in the assessment scale, reaching $8.4 \pm 0.8$ points, on average.

Table 1. Clinical trials with a control group and their characteristics

\begin{tabular}{|c|c|c|c|c|c|c|}
\hline Authors & Objectives & Kind of Study & $\begin{array}{c}\text { Counter } \\
\text { intervention }\end{array}$ & Population & $\begin{array}{l}\text { PEDro } \\
\text { final score }\end{array}$ & Results \\
\hline González-Iglesias et al. ${ }^{2}$ & $\begin{array}{c}\text { Short-term effects on pain and } \\
\text { ROM in patients post cervical } \\
\text { "whip" }\end{array}$ & $\begin{array}{l}\text { Randomized } \\
\text { clinical essay }\end{array}$ & Placebo & $\begin{array}{l}41 \text { patients with } \\
\text { post "whip" pain }\end{array}$ & 9 & Superior to CG \\
\hline $\begin{array}{l}\text { Saavedra-Hernández } \\
\text { et al.." }\end{array}$ & $\begin{array}{l}\text { Compare KT manipulation in } \\
\text { individuals with mechanical } \\
\text { cervical pain on pain, disability } \\
\text { and ROM }\end{array}$ & $\begin{array}{l}\text { Randomized } \\
\text { clinical essay }\end{array}$ & Thrust & $\begin{array}{l}80 \text { patients with } \\
\text { mechanical } \\
\text { cervical pain }\end{array}$ & 9 & Similar to CG \\
\hline $\begin{array}{l}\text { García Llopis e } \\
\text { Campos Aranda }\end{array}$ & $\begin{array}{l}\text { Assess whether the KT improves } \\
\text { the effectiveness of the physical } \\
\text { therapy treatment on the } \\
\text { mechanical cervical pain, ROM } \\
\text { and quality of life }\end{array}$ & $\begin{array}{l}\text { Controled clinical } \\
\text { essay }\end{array}$ & $\begin{array}{l}\text { Conventional } \\
\text { physical therapy }\end{array}$ & $\begin{array}{l}10 \text { patients with } \\
\text { mechanical } \\
\text { cervical pain }\end{array}$ & 9 & Superior to CG \\
\hline $\begin{array}{l}\text { Kaya, Zinnuroglu e } \\
\text { Tugcuio }^{10}\end{array}$ & $\begin{array}{l}\text { Compare KT with conventional } \\
\text { physical therapy in patients } \\
\text { with shoulder impingement } \\
\text { syndrome, assessing the disability }\end{array}$ & $\begin{array}{l}\text { Controled clinical } \\
\text { essay }\end{array}$ & $\begin{array}{l}\text { Electro- } \\
\text { thermotherapy }\end{array}$ & $\begin{array}{l}55 \text { patients with } \\
\text { impact syndrome }\end{array}$ & 5 & Superior to CG \\
\hline $\begin{array}{l}\text { Thelen, Dauber e } \\
\text { Stoneman }{ }^{7}\end{array}$ & $\begin{array}{l}\text { Compare the KT with } \\
\text { simulacrum, in young people with } \\
\text { shoulder pain, on pain, disability } \\
\text { and ROM }\end{array}$ & $\begin{array}{l}\text { Randomized } \\
\text { clinical essay, } \\
\text { Double blind }\end{array}$ & Placebo & $\begin{array}{l}42 \text { patients with } \\
\text { diagnosis of impact } \\
\text { S/ tendinopathy } \\
\text { of RC }\end{array}$ & 9 & Similar to CG \\
\hline Chang et $a l .^{9}$ & $\begin{array}{c}\text { Short-term effects on pain, } \\
\text { strength and proprioception } \\
\text { of baseball players with medial } \\
\text { epicondylitis }\end{array}$ & $\begin{array}{l}\text { Case control study } \\
\text { with repeated } \\
\text { measures }\end{array}$ & Control; placebo & $\begin{array}{l}10 \text { baseball players } \\
\text { with medial } \\
\text { epicondylitis }+17 \\
\text { healthy volunteers }\end{array}$ & 8 & $\begin{array}{c}\text { Semelhante ao } \\
\text { placebo }\end{array}$ \\
\hline Paoloni et al. ${ }^{3}$ & $\begin{array}{l}\text { Effects of KT on pain, disability } \\
\text { and muscle function in individuals } \\
\text { with chronic low back pain }\end{array}$ & $\begin{array}{c}\text { Phase I: } \\
\text { intra-subject } \\
\text { assessment (pre/ } \\
\text { post) } \\
\text { Phase II: Controled } \\
\text { clinical essay }\end{array}$ & $\begin{array}{l}\text { KT + exercises; } \\
\text { exercises }\end{array}$ & $\begin{array}{l}39 \text { patients with } \\
\text { chronic low back } \\
\text { pain }\end{array}$ & 9 & $\begin{array}{c}\text { Similar to the } 2 \\
\text { groups }\end{array}$ \\
\hline Castro-Sánchez et al. ${ }^{5}$ & $\begin{array}{c}\text { Effects of KT on pain, disability } \\
\text { and kinesiophobia in individuals } \\
\text { with chronic low back pain }\end{array}$ & $\begin{array}{l}\text { Randomized } \\
\text { clinical essay }\end{array}$ & Placebo & $\begin{array}{l}60 \text { patients with } \\
\text { chronic low back } \\
\text { pain }\end{array}$ & 9 & Superior to CG \\
\hline Akbas, Atay e Yüksel ${ }^{6}$ & $\begin{array}{l}\text { Effects of } \mathrm{KT} \text { in the patellofemoral } \\
\mathrm{S} \text {, assessing pain, function and } \\
\text { flexibility }\end{array}$ & $\begin{array}{l}\text { Randomized } \\
\text { clinical essay }\end{array}$ & $\begin{array}{l}\text { FM/stretching } \\
\text { without KT }\end{array}$ & $\begin{array}{l}31 \text { women with } \\
\text { patellofemoral S }\end{array}$ & 7 & Similar to CG \\
\hline Nambi e Shah ${ }^{8}$ & $\begin{array}{l}\text { Compare KT to Mulligan } \\
\text { mobilization in subacute ankle } \\
\text { sprains, on pain and ROM }\end{array}$ & $\begin{array}{l}\text { Clinical essay } \\
\text { with convenience } \\
\text { sample }\end{array}$ & MWM & $\begin{array}{l}30 \text { patients with } \\
\text { subacute ankle } \\
\text { sprain (inversion in } \\
\text { ankle) }\end{array}$ & 5 & Inferior to CG \\
\hline
\end{tabular}


In only one study the KT was less efficient, in ankle sprain, providing a reduction of pain (55.6\%), but this being a smaller improvement when compared to joint mobilization (MWM) (74.9\%), since both groups received only three sessions per week. However, it was one of the studies which reached the lowest scores on the PEDro scale (5 points), representing lower quality in conducting the survey ${ }^{8}$.

Most authors described hypotheses for the hypoalgesic mechanism attributed to the application of the KT. Among these, the most cited ones were the following. The tension provided by the tape generates afferent stimuli, facilitating the inhibitory mechanism of pain (gate control theory); the tape provides a sensorimotor feedback that only allows movements that cause minimal mechanical irritation of the tissues, hence less pain occurs $2,5,7,8,10,18$; another theory was based on the condition of mechanical cervical pain, in which the authors did not directly emphasized a mechanism for pain reduction, but they claim that this would occur, as the technique provides increased range of joint motion ${ }^{16 ;}$ only one study mentioned the possibility of improvement occurring by the increase of circulation in the injured area ${ }^{9}$.

The most accepted idea so far is the gate control theory, in which the mechanical stimuli provided by the KT would act through fast-conducting fibers $(\mathrm{A} \beta)$, performing synapses with inhibitory interneurons when reaching the Roland's Gelatinous Substance (posterior horn of the spinal cord), causing the closure of the gate and therefore, not allowing the passage of notion receptive stimulus ( $\mathrm{C}$ and $\mathrm{A} \delta$ fibers $)^{19}$. Another easily elucidative thesis in practice would be the immediate effect that can be obtained by applying the KT across the muscle or the compromised tendon (moderate to intense compression), previously or after physical therapy session. One can test this hypothesis, not yet scientifically explained, in cases of lateral epicondylitis of the elbow (tennis elbow), tendinopathy of the "goose foot" (sartorius, gracilis and semitendinous), patella (jumper's knee) and calcaneus. It is believed that this way of using the tape decreases the load on a muscle or tendon for modifying the point of the lever (internal moment arm), decreasing the applied strength at the affected area, and as a consequence, decreasing the pain. It would be a literal mechanical effect, which gives in as the tape loses its ability to maintain the pressure on the area, due to the repeated use of the limb, but that, in most cases, provides greater pain relief when compared to standard applications on these regions.
After checking these studies on the use of KT in varied conditions, it may be noted that after the muscle/joint is wrapped by the band, the physical therapist should begin or previously apply some kind of method or correction technique to the cause of the injury. As elucidated, the application of KT is suggested as a short term additional strategy for the reduction of pain, such as chronic low back pain, although it does not replace the need for exercising. Therefore, the KT tape is described as an alternative or complementary treatment, as an option when an immediate and short-duration effect, by application, is desired, although it shall not be used as the only form of treatment. It is suggested the association with other techniques and resources (manual therapy, muscle strengthening and electrothermal and phototherapy $)^{10}$.

Up to date, no work has been developed in order to evaluate the long-term effects of KT, the maximum period was 4-6 weeks, with similar values obtained between the observed groups $s^{2,3,5-7,18}$.

The combination of low cost, limited risk of complications and immediate reduction in pain (although small) makes the application of KT a considerable plan of action, even if literature cannot accurately describe its mechanism of action, yet $^{5}$.

\section{CONCLUSION}

The KT produces hypoalgesic effects similar to those of other experimental groups $(8.4 \pm 0.8$ points, PEDro scale), which, clinically, does not justify its use as a primary analgesic technique. Three studies of high methodological quality (9 points, PEDro scale) suggest that its effects on pain were higher, in the short term (24 hours after application), and its results are, mostly, described as beneficial, however there is no scientific evidence that these effects may be prolonged.

\section{REFERENCES}

1. Kase K, Wallis J, Kase T. Clinical therapeutic applications of the Kinesio Taping Method. 2 ed. Tokyo: Ken Ikai; 2003. p. 19-39.

2. González-Iglesias J, Fernández-De-Las-Peñas C, Cleland JA, Huijbregts P. Del Rosario Gutiérrez-vega M. Short-term effects of cervical Kinesio Taping on pain and cervical range of motion in patients with acute whiplash injury: a randomized clinical trial. J Orthop Sports Phys Ther. 2009;39(7):515-21. 
3. Paoloni M, Bernetti A, Fratocchi G, Mangone M, Parrinelo L, Del Pilar Cooper M, et al. Kinesio Taping applied to lumber muscles influences clinical and electromyographic characteristics in chronic low back pain patients. Eur J Phys Rehabil Med. 2011:47(2):237-44.

4. Ribeiro MO, Rahal RO, Kokanj AS, Bittar DP. O uso da bandagem elástica Kinesio no controle da sialorréia em crianças com paralisia cerebral. Acta Fisiatr. 2009;16(4):168-72.

5. Castro-Sánchez AM, Lara-Palomo IC, Matarán-Peñarrocha GA, Fernández-Sánchez M, Sánches-Labraca $N$, Arroyo-Morales $M$. KinesioTaping reduces disability and pain slightly in chronic nonspecific low back pain: a randomised trial. J Physiother. 2012;58(2):89-95.

6. Akbas E, Atay AO, Yüksel I. The effects of additional kinesio taping over exercise in the treatment of patellofemoral pain syndrome. Acta Orthop Traumatol Turc. 2011;45(5):335-41.

7. Thelen MD, Dauber JA, Stoneman PD. The clinical efficacy of Kinesio Tape for shoulder pain: a randomized, double-blind, clinical trial. J Orthop Sports Phys Ther. 2008;38(7):389-95.

8. Nambi G, Shah BT. Kinesio taping versus Mulligan's mobilization with movement in sub-acute lateral ankle sprain in secondary school Hockey players - comparative study. Int J Pharmac Health Care. 2012;2(2):136-49.

9. Chang HY, Wang $\mathrm{CH}$, Chou KY, Cheng SC. Could forearm Kinesio Taping improve strength, force sense and pain in baseball pitchers with medial epicondylitis? Clin J Sport Med. 2012;22(4):327-33.

10. Kaya E, Zinnuroglu M, Tugcu I. Kinesio taping compared to physical therapy modalities for the treatment of shoulder impingement syndrome. Clin Rheumatol. 2011;30(2):201-7.

11. Jaraczewska E, Long C. Kinesio taping in stroke: improving functional use of the upper extremity in hemiplegia. Top Sroke Rehabil. 2006;13(3):31-42
12. Santos JCC, Giorgetti MJS, Torello EM, Meneghetti CHZ, Ordenes IEU. A influência da Kinesio Taping no tratamento da subluxação de ombro no Acidente Vascular Cerebral. Rev Neurocienc 2010;18(3):335-40.

13. Cortesi M, Cattaneo D, Jonsdottir J. Effect of kinesio taping on standing balance in subjects with multiple sclerosis: a pilot study. NeuroRehabilitation. 2011;28(4):365-72.

14. Stockheimer KR. Kinesio Taping \& Iymphoedema: applied Kinesio Taping for lymphoedema/chronic swelling of the arm and/or breast after a mastectomy and axilla lymph node removal. Adv Healing 2006,22-3.

15. Tsai HJ, Hung HC, Yang JL, Huang CS, Tsauo JY. Could Kinesio tape replace the bandage in decongestive lymphatic therapy for breastcancer-related Iymphedema? A pilot study. Support Care Cancer. 2009;:17(11):1353-60.

16. García Llopis L, Campos Aranda M. Intervención fisioterápica con vendaje neuromuscular en pacientes con cervicalgia mecánica. Un estudio piloto. Fisioter. 2012;34(5):189-95.

17. Verhagen AP, de Vet HC, de Bie RA, Kessels AG, Boers M, Bouter LM, et al. The Delphi list: a criteria list for quality assessment of randomised clinical trials for conducting systematic reviews developed by Delphi consensus. J Clin Epidemiol. 1998;51(12):1235-41.

18. Saavedra-Hernández M, Castro-Sánchez AM, Arroyo-Morales M, Cleland JA, Lara-Palomo IC, Fernández-de-Las-Peñas C. Short-term effects ok kinesio taping versus cervical thrust manipulation in patients with mechanical neck pain: a randomized clinical trial. J Orthop Sports Phys Ther. 2012;42(8):724-30.

19. Gosling AP. Mecanismos de ação e efeitos da fisioterapia no tratamento da dor. Rev Dor. 2013;13(1):65-70. 